\title{
Profil penelitian keterampilan membaca cepat pada jurnal pendidikan bahasa dan sastra Indonesia dalam PPJB-SIP
}

(Research profiles of speed reading skills in Indonesian language and literature education journals-PPJB-SIP)

\section{Arif Setiawan ${ }^{I^{*}}$, Musaffak ${ }^{2}$}

Program Studi Pendidikan Bahasa Indonesia, Fakultas Keguruan dan Ilmu Pendidikan, Universitas Muhammadiyah Malang, J1. Tlogomas 246 Malang, Indonesia

1arifsetiawan@umm.ac.id, musaffak@umm.ac.id²

*Corresponding author: arifsetiawan@umm.ac.id

\begin{tabular}{l} 
Sejarah Artikel Diterima: I0 Agustus 202I Direvisi: I2 Oktober 202I \\
ABSTRAK \\
\hline \hline Perkembangan teknologi telah membuat sumber informasi menjadi semakin beragam. Untuk memahami informasi yang \\
beragam dan lebih variatif diperlukan keterampilan membaca tertentu, salah satunya adalah keterampilan membaca cepat. \\
Penelitian ini bertujuan mendeskripsikan (I) jenis penelitian (2) jenis penelitian kuantitatif yang digunakan untuk \\
menganalisis keterampilan membaca cepat, (3) subjek penelitian yang digunakan peneliti untuk menelaah keterampilan \\
membaca cepat, (4) instrumen pengumpulan data yang digunakan oleh peneliti untuk mengetahui keterampilan membaca \\
cepat, (5) metode analisis data yang digunakan oleh peneliti untuk mengetahui keterampilan membaca cepat, dan (6) profil \\
penelitian keterampilan membaca cepat dari tahun ke tahun. Metode penelitian dalam penelitian ini adalah analisis isi. \\
Sumber data dalam penelitian ini adalah I5 artikel yang ditulis dalam jurnal yang tergabung dalam website dan database \\
PPJB-SIP, sehingga data dalam penelitian ini merupakan hasil analisis isi artikel penelitian tentang keterampilan membaca \\
cepat. Instrumen yang digunakan dalam penelitian ini adalah pedoman analisis isi. Hasil penelitian menunjukkan bahwa (I) \\
jenis penelitian yang dominan digunakan oleh peneliti adalah jenis penelitian kuantitatif, (2) desain penelitian eksperimen \\
merupakan desain penelitian yang paling dominan digunakan, (3) subjek penelitian yang digunakan didominasi oleh siswa \\
kelas VII SMP, (4) instrumen tes merupakan instrumen yang paling sering digunakan untuk menyelidiki keterampilan \\
membaca cepat, (5) metode analisis data yang lebih dominan adalah uji-t, dan (6) penelitian tentang keterampilan membaca \\
cepat dilakukan dari tahun 20I4-2020 dengan hasil tertinggi pada tahun 20I8. Akhirnya, penelitian ini akan bermanfaat \\
dalam memberikan informasi berharga tentang profil keterampilan membaca cepat, serta dasar untuk mengaktifkan \\
keterampilan membaca cepat di era informasi digital.
\end{tabular}

\section{Kata Kunci Keterampilan, Membaca cepat, Profil}

\section{ABSTRACT}

Technological developments have made information sources more diverse. Certain reading skills are needed to understand diverse and more varied information, one of which is speed reading skills. This study aims to describe (I) types of research (2) types of quantitative research used to analyze speed reading skills, (3) research subjects used by researchers to examine speed reading skills, (4) data collection instruments used by researchers to determine skills speed reading, (5) data analysis methods used by researchers to determine speed reading skills, and (6) research profiles of speed reading skills from year to year. The research method in this research is content analysis. The data sources in this study were I5 articles written in journals incorporated in the PPJB-SIP website and database, so the data in this study is the result of content analysis of research articles about speed reading skills. The instrument used in this study is a content analysis guideline. The results showed that (I) the dominant type of research used by the researcher was quantitative research, (2) the experimental research design was the most dominant research design used, (3) seventh grade junior high school students dominated the research subjects used, (4) the test instrument is the most frequently used instrument to investigate speed reading skills, (5) the more dominant data analysis method is the t-test, and (6) research on speed reading skills was conducted from 20I4-2020 with the highest results in 2018. Finally, this research will provide valuable information about the profiles of speed reading skills and the basis for activating speed reading skills in the digital information age.

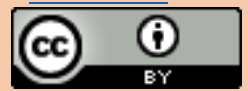


How to Cite Setiawan, A., \& Musaffak, M. (202I). Profil penelitian keterampilan membaca cepat pada jurnal pendidikan bahasa dan sastra Indonesia dalam PPJB-SIP. KEMBARA: Jurnal Keilmuan, Bahasa, Sastra dan Pengajarannya (e-Journal), 7(2), 463-475. https://doi.org/I0.22219/kembara.v7i2.17889

\section{PENDAHULUAN}

Membaca merupakan salah satu keterampilan yang harus dimiliki oleh siapa pun untuk memperoleh informasi dan ilmu pengetahuan dari berbagai sumber (Sinin, 20I5). Informasi dan ilmu pengetahuan yang diperoleh akan menambah skemata yang membentuk wawasan baru (Nurhayati, 2015; Sinin, 2015). Wawasan baru yang didapatkan akan sangat berguna untuk menghadapi abad 2I, dimana ditandai dengan keterbukaan sumber informasi, globalisasi, dan ilmu pengetahuan (Musianto, 2004; Saputri, Sajidan, Rinanto, Afandi, \& Prasetyanti, 2019). Keterbukaan informasi baru pada abad-2I ditandai dengan pergeseran sumber informasi yang berasal dari buku menuju halaman layar, serta perubahan dari media massa cetak menuju media massa online/daring (Brozo \& Johns, I986; Yen, 2012). Pergeseran tersebut secara alamiah akan membuat setiap masyarakat harus menerima ledakan informasi digital yang tidak dapat dibendung lagi (Rau, Zheng, Guo, \& Li, 20I8).

Berlimpahnya sumber informasi dalam bentuk digital tak ayal menjadikan setiap individu harus lebih cepat dalam menerima dan membaca sumber informasi dari sumber yang beragam (Nurani, Suhita, \& Suryanto, 2017). Hal ini didasarkan pada kondisi bahwa keberagaman informasi menuntut pemahaman dari setiap individu untuk memperoleh informasi dengan cepat (Maryamah \& Effendy, 2019), pemeroleh informasi tersebut dapat dilakukan dengan keterampilan membaca cepat (Inawati \& Sanjaya, 2018). Keterampilan membaca cepat yang dimaksudkan, tentu saja tidak serta merta mengorbankan proses membaca yang dilakukan dengan ala kadarnya. Keterampilan membaca cepat yang dilakukan bertujuan untuk mencari informasi dari bahan bacaan yang didasarkan pada keadaan, suasana, dan jenis bacaan yang dihadapinya (Maryamah \& Effendy, 2019), tentu saja membaca cepat tidak dilakukan setiap kali melakukan proses membaca, melainkan dalam beberapa kondisi tertentu (Nurhayati, 20I5). Keterampilan membaca cepat yang dilakukan, juga bersandar pada proses pemahaman terhadap teks yang dibaca (Maryamah \& Effendy, 2019), sehingga dapat dikatakan keterampilan membaca cepat tidak hanya menekankan pada kecepatan saja, melainkan juga menekankan pada pemahaman isi bacaan (Kamalasari, 2012; Nurani et al., 2017).

Keterampilan membaca cepat dalam dunia pendidikan memiliki peran yang sangat fundamental. Hal ini didasarkan pada realitas bahwa seluruh aktivitas dalam dunia pendidikan lebih menekankan pada tugas membaca (Maryamah \& Effendy, 2019). Realitas tersebut diperkuat dengan Standar Nasional Pendidikan yang menyatakan bahwa pembelajaran membaca dan menulis sangat fundamental perannya di sekolah (Nurhayati, 2015). Kehadiran Standar Nasional Pendidikan (SNP) tentang keterampilan membaca semakin menguatkan bahwa dewasa ini masyarakat telah terjangkiti penyakit malas membaca. Kondisi ini tentu tidak ideal bagi keberlangsungan pendidikan di Indonesia, karena memasuki abad-2I semua informasi yang tersaji lebih dominan dalam bentuk tertulis. Hal ini semakin menguatkan bahwa pembelajaran membaca serta bentuk evaluasinya harus menjadi perhatian pemerintah (Maryamah \& Effendy, 2019).

Perhatian pemerintah terhadap pembelajaran membaca harus menjadi salah satu langkah pengembangan pendidikan dengan mengakomodasi segala bentuk optimalisasi kompetensi yang dimiliki oleh siswa (Abiyanti, 2017; Susetyarini \& Fauzi, 2020). Perkembangan pendidikan sendiri tidak dapat terlepas dari sejumlah penelitian yang telah memberikan kontribusi yang berlimpah tentang bagaimana mempertahankan peningkatan kualitas pada proses pembelajaran (Nurani et al., 20I7; Susetyarini \& Fauzi, 2020). Informasi yang didapatkan dari beberapa penelitian tersebut, seringkali dijadikan sebagai landasan dasar dalam menentukan arah kebijakan dan perencanaan pembelajaran yang dirancang oleh guru dan dosen (Susetyarini \& Fauzi, 2020), khususnya mengenai keterampilan membaca cepat. Sesuai dengan kebijakan pemerintah yang tertuang dalam Standar Nasional Pendidikan (SNP) yang menyatakan bahwa keterampilan membaca cepat harus dikuasai oleh siswa di sekolah dasar sampai sekolah menengah (Nurani 
et al., 2017). Keterampilan membaca cepat pada tingkat Sekolah Dasar (SD) memiliki standar siswa dapat membaca sejumlah 75 kata per menit, 250 kata per menit untuk siswa Sekolah Menengah Pertama (SMP), dan 350 kata untuk siswa Sekolah Menengah Atas (SMA) (Maryamah \& Effendy, 2019). Rentetan data tersebut semakin menguatkan bahwa keterampilan membaca cepat merupakan keterampilan yang wajib dimiliki pada abad 2I ini.

Berkaitan dengan pentingnya keterampilan membaca cepat, beberapa penelitian tentang keterampilan membaca cepat telah banyak dilakukan. Beberapa kajian yang paling sering dilakukan terhadap keterampilan membaca cepat adalah dalam bentuk Penelitian Tindakan Kelas (PTK), seperti penelitian yang dilakukan oleh Abiyanti (2017); Amalia (2019); Artanto (2009); Hosen (2016); Nurani et al., (2017); Nurhayati (2015); Permana, Sulistyowarni, \& Irmayanti (2016); Pratama \& Yuniawan (20I5); Sinin (20I5); dan Zuhara (20I5). Penelitian lainnya mengenai keterampilan membaca cepat yang dikaji dalam bentuk analisis deskriptif dilakukan oleh Ahyar \& Syahriandi (20I5); Inawati \& Sanjaya (20I8); Januarti, Dibia, \& Widiana (2016); Mulyani (20II); dan Sari, Zulela, \& Boeriswati (2017). Di sisi lain, studi yang mengaji tentang profil keterampilan membaca cepat pada hasil riset yang telah dipublikasikan dalam bentuk artikel ilmiah belum pernah dilakukan. Studi semacam ini akan sangat bermanfaat dalam mengungkap berbagai informasi berharga yang dapat digunakan sebagai dasar untuk merancang pembelajaran. Selain itu, informasi yang dihasilkan dari studi semacam ini akan menjadi bahan evaluasi sejauh mana optimalisasi keterampilan membaca cepat siswa di tingkat sekolah dasar sampai menengah. Penelitian ini bertujuan untuk menjawab pertanyaan (I) bagaimana jenis penelitian yang digunakan untuk menganalisis keterampilan membaca cepat? (2) bagaimana jenis penelitian kuantitatif yang digunakan untuk mengetahui keterampilan membaca cepat? (3) bagaimana subjek penelitian yang digunakan oleh peneliti untuk mengetahui keterampilan membaca cepat? (4) bagaimana instrumen pengumpulan data yang digunakan oleh peneliti untuk mengetahui keterampilan membaca cepat? (5) bagaimana metode analisis data yang digunakan oleh peneliti untuk mengetahui keterampilan membaca cepat? (6) bagaimana profil penelitian keterampilan membaca cepat dari tahun ke tahun?

\section{METODE}

Penelitian ini menggunakan model analisis isi yang lebih difokuskan pada temuan yang berasal dari berbagai penelitian yang telah dipublikasikan pada jurnal ilmiah dalam PPJB-SIP di Indonesia. Metode yang digunakan dalam penelitian ini mirip dengan yang telah digunakan oleh Susetyarini \& Fauzi (2020). Data dalam penelitian ini dikumpulkan dari hasil analisis isi yang dilakukan pada artikel penelitian pendidikan bahasa dan sastra Indonesia. Seluruh artikel yang diambil dari jurnal pendidikan bahasa dan sastra Indonesia yang telah terdaftar dalam Perkumpulan Pengelola Jurnal Bahasa, Sastra Indonesia, dan Pengajarannya (PPJB-SIP) pada Bulan Maret 202I. PPJB-SIP merupakan perkumpulan Pengelola Jurnal Bahasa, Sastra Indonesia, dan Pengajarannya di Indonesia. Secara keseluruhan terdapat II3 jurnal pendidikan bahasa dan sastra Indonesia yang berada di database PPJB-SIP. Selanjutnya, semua artikel yang mengulas mengenai keterampilan membaca cepat dikumpulkan dari masing-masing jurnal pendidikan bahasa dan sastra Indonesia yang terdaftar di PPJB-SIP. Semua artikel yang dianalisis dalam penelitian ini telah diterbitkan secara online sebelum Maret 202I. Dari sekian banyak artikel yang telah dikumpulkan, terdapat I5 artikel yang mengaji mengenai keterampilan membaca cepat, sebanyak I5 artikel tersebutlah yang dianalisis dalam penelitian ini.

Instrumen penelitian yang digunakan dalam penelitian ini adalah pedoman analisis isi yang berisi aspek terkait dengan artikel yang diamati sebagaimana Tabel I. Terdapat sebanyak enam aspek utama yang ditinjau untuk analisis isi dalam penelitian ini. Aspek-aspek tersebut meliputi (I) jenis penelitian, (2) jenis penelitian kuantitatif, (3) subjek penelitian, (4) instrumen pengumpulan data, (5) metode analisis data, (6) tahun terbit artikel. Kategori yang ditunjukkan pada Tabel I diadaptasi dari model penelitian (Susetyarini \& Fauzi, 2020). Untuk aspek jenis penelitian diperinci kembali menjadi dua sub-aspek yang terdiri dari jenis penelitian secara umum dan desain penelitian kuantitatif. 
Tabel I

Aspek dan Kategori yang Digunakan sebagai Indikator untuk Melakukan Analisis Isi

\begin{tabular}{|c|c|c|}
\hline Aspek & & Kategori \\
\hline \multirow{2}{*}{ Jenis Penelitian } & I.I $\mathrm{R}$ and $\mathrm{D}$ & I.3 Penelitian Kualitatif \\
\hline & I.2 CAR & I.4 Penelitian kuantitatif \\
\hline \multirow{4}{*}{$\begin{array}{l}\text { Jenis Penelitian } \\
\text { Kuantitatif }\end{array}$} & 2.I Studi Pengamatan & 2.5 Desain Experimental sebenarnya \\
\hline & 2.2 Penelitian Korelasi & 2.6 Desain Kuasi Eksperimen \\
\hline & 2.3 Penelitian Survei & 2.7 Desain Ekspost Facto \\
\hline & 2.4 Desain Pra-Experimental & 2.8 Tidak Terkategori \\
\hline \multirow{6}{*}{ Subjek Penelitian } & 3.I Siswa Kelas VII SMP & 3.7 Mahasiswa \\
\hline & 3.2 Siswa Kelas VIII SMP & 3.8 Mahasiswa Pascasarjana \\
\hline & 3.3 Siswa Kelas IX SMP & 3.9 Guru SMP \\
\hline & 3.4 Siswa Kelas X SMA & 3.I0 Guru SMA \\
\hline & 3.5 Siswa Kelas XI SMA & 3.I I Dosen \\
\hline & 3.6 Siswa Kelas XII SMA & 3.12 Lainnya \\
\hline \multirow{3}{*}{$\begin{array}{l}\text { Instrumen } \\
\text { Pengumpulan Data }\end{array}$} & 4.I Lembar Kuesioner & 4.4 Lembar Wawancara \\
\hline & 4.2 Lembar Observasi & 4.5 Tidak teridentifikasi \\
\hline & 4.3 Lembar tes & 4.6 Lainnya \\
\hline \multirow{5}{*}{ Metode Analisis Data } & 5.I Mean & 5.6. ANCOVA \\
\hline & 5.2 Presentase & 5.7 Korelasi \\
\hline & $5.3 \mathrm{~N}-$ Gain & 5.8 Tidak teridentifikasi \\
\hline & $5.4 \mathrm{Uji}-\mathrm{T}$ & 5.9 Lainnya \\
\hline & 5.5 ANOVA & \\
\hline \multirow{4}{*}{ Tahun Terbit Artikel } & 6.12014 & 6.52018 \\
\hline & 6.22015 & 6.62019 \\
\hline & 6.32016 & 6.72020 \\
\hline & 6.42017 & \\
\hline
\end{tabular}

\section{HASIL DAN PEMBAHASAN}

Hasil penelitian mengenai profil penelitian keterampilan membaca cepat yang telah dilakukan mendapatkan informasi sebagaimana tujuan penelitian yang meliputi (I) jenis penelitian yang digunakan untuk menganalisis keterampilan membaca cepat, (2) jenis penelitian kuantitatif yang digunakan untuk mengetahui keterampilan membaca cepat, (3) subjek penelitian yang digunakan oleh peneliti untuk mengetahui keterampilan membaca cepat, (4) instrumen pengumpulan data yang digunakan oleh peneliti untuk mengetahui keterampilan membaca cepat, (5) metode analisis data yang digunakan oleh peneliti untuk mengetahui keterampilan membaca cepat, (6) profil penelitian keterampilan membaca cepat dari tahun ke tahun. Adapun uraian dari masing-masing data tersebut diuraikan sebagaimana berikut.

\section{Jenis Penelitian}

Berdasarkan Gambar I menunjukkan bahwa jenis penelitian yang sangat dominan digunakan untuk menyelediki keterampilan membaca cepat adalah penelitian kuantitatif. Jumlah penelitian kuantitatif menunjukkan jenis penelitian yang sangat tinggi dibandingkan dengan jenis penelitian lainnya. Hal ini sejalan dengan penelitian sebelumnya yang telah dilakukan, bahwa kebanyakan para peneliti lebih menyukai menggunakan jenis penelitian kuantitatif dalam melakukan penelitian di bidang pendidikan (Bozkaya, Aydin, \& Kumtepe, 2012; Chang, Chang, \& Tseng, 2010; Goktas et al., 20I2). Kondisi tersebut membuktikan bahwa jenis penelitian kualitatif masih dianggap hal yang baru dalam penelitian pendidikan (Sharma, 2013). Akan tetapi, dewasa ini tren penelitian kualitatif mulai menunjukkan peningkatan (Shakouri \& Nazari, 2014), serta telah merambah dan menargetkan penelitian sosial, salah satunya penelitian pendidikan (Mohajan, 2018). Berdasarkan realitas yang telah terjadi, telah memberikan keuntungan tersendiri pada pendekatan kualitatif untuk mendefinisikan fenomena sosial atau pendidikan secara rinci dan komprehensif (Kapborg \& Berterö, 2003). Oleh karena itu, minimnya keberadaan penelitian kualitatif telah menjadikan peluang baik untuk melanjutkan penelitian dengan menggunakan jenis penelitian kualitatif, serta memfokuskan permasalahan pada keterampilan membaca cepat. 


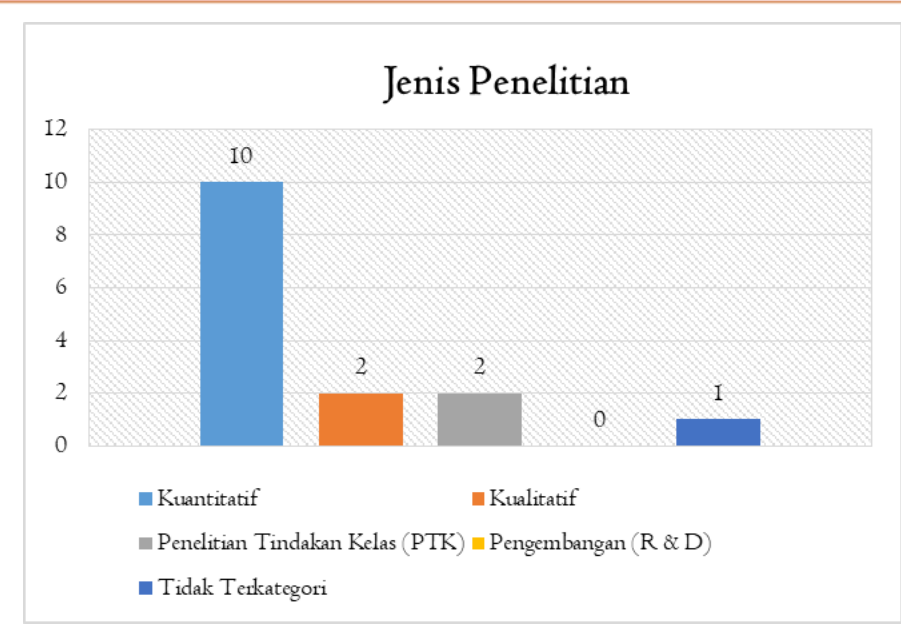

Gambar I Jenis Penelitian Keterampilan Membaca Cepat

Temuan lainnya dalam penelitian ini, menunjukkan bahwa penelitian $\mathrm{R}$ and $\mathrm{D}$ (pengembangan) tentang keterampilan membaca cepat masih sangat minim. Hal ini sedikit berbeda dengan temuan penelitian yang menyatakan bahwa $\mathrm{R}$ and $\mathrm{D}$ merupakan penelitian yang paling banyak dipublikasikan pada tahun 2017 (Fauzi \& Pradipta, 2018). Selain itu, penelitian R and D dikategorikan sebagai jenis penelitian terbaru dalam penelitian pendidikan (Arifin, 2020). Penelitian R and D sering menghasilkan produk pendidikan berdasarkan hasil dan proses penelitian yang sebelumnya sudah dilakukan. Adapun produk yang dihasilkan dari penelitian R and D meliputi buku dan modul (Suciyati \& Adian, 2018), atau bahan ajar (Muhibbin \& Sumarjoko, 2016). Berkaitan dengan hasil penelitian tersebut dapat ditarik kesimpulan bahwa dari beberapa penelitian $\mathrm{R}$ and $\mathrm{D}$ yang telah dilakukan belum menjadikan keterampilan membaca cepat sebagai dasar untuk mengembangkan penelitian mereka.

\section{Jenis Penelitian Kuantitatif}

Berdasarkan Gambar 2, profil keterampilan membaca cepat dengan menggunakan jenis penelitian kuantitatif sangat didominasi oleh desain eksperimen. Pemilihan desain eksperimen menunjukkan bahwa para peneliti lebih memilih untuk menggunakan jenis penelitian yang paling baik dan tepat untuk mengulas masalah pendidikan (Abiyanti, 2017; Mulyadi, 201 I; Permana et al., 2016; Susetyarini \& Fauzi, 2020), khususnya dalam penelitian keterampilan membaca cepat. Desain eksperimen yang lebih sering digunakan dalam penelitian keterampilan membaca cepat adalah kuasi eksperimen. Hal ini didasarkan pada fakta bahwa desain kuasi eksperimen memberikan informasi dan hasil penelitian yang lebih jelas daripada jenis penelitian kuantitatif lainnya (Mulyani, 20II; Trihantoro, Hidayat, \& Chanum, 20I6). Selain itu, penelitian kuasi eksperimen juga memiliki keunggulan tersendiri, khususnya pada tidak adanya batasan terhadap proses randomisasi, serta di waktu yang bersamaan juga dapat mengontrol ancaman yang berasal dari tingkat validitas (Mulyani, 20I I; Suniati, Sadia, \& Suhandana, 2013; Trihantoro et al., 2016). Berdasarkan hasil penelitian ini, tindak lanjut yang dapat dilakukan oleh peneliti-peneliti selanjutnya adalah melakukan penelitian dengan menggunakan jenis penelitian eksperimen lain untuk menggali informasi tentang keterampilan membaca cepat. Hal ini diharapkan dapat melengkapi profil penelitian mengenai keterampilan membaca cepat yang sudah dilakukan sebelumnya. 


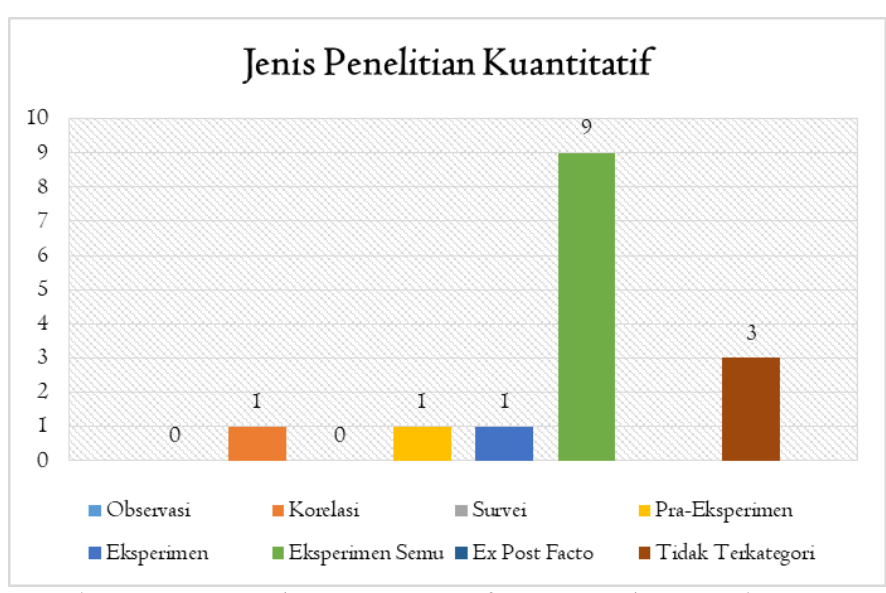

Gambar 2 Jenis Penelitian Kuantitatif Keterampilan Membaca Cepat

\section{Subjek Penelitian}

Berdasarkan grafik di Gambar 3, menunjukkan bahwa secara urutan, subjek penelitian yang digunakan lebih dominan pada subjek siswa kelas VII. Selanjutnya diikuti secara berurutan dari siswa kelas VIII, kelas IX Sekolah Menengah Pertama (SMP), kelas XI SMA dan mahasiswa di posisi selanjutnya. Secara urutan menunjukkan bahwa posisi pertama ditempati oleh siswa kelas VII SMP dengan jumlah sebanyak 7 peneliti yang menggunakannya sebagai subjek penelitian. Selanjutnya diikuti dengan siswa kelas VIII sebanyak 4 peneliti menggunakannya sebagai subjek penelitian. Dilanjutkan dengan siswa kelas IX SMP yang berada di urutan ketiga sebanyak 2 peneliti yang menggunakannya sebagai subjek penelitian. Terakhir ditutup dengan urutan keempat pada siswa kelas XI SMA dan mahasiswa dengan masing-masing sebanyak I peneliti yang menggunakannya sebagai subjek penelitian.

Masing-masing urutan menunjukkan ketimpangan jumlah yang cukup mencolok pada penggunaan subjek penelitian. Dimana siswa kelas VII SMP menjadi salah satu subjek penelitian yang sangat dominan digunakan dalam penelitian keterampilan membaca cepat. Hal ini sejalan dengan pendapat Amalia (2019) dan Trihantoro et al. (2016) bahwa keterampilan membaca cepat sangat tepat dijarakkan pada siswa Sekolah Menengah Pertama (SMP) khususnya kelas awal. Selain itu, keterampilan membaca cepat juga menjadi salah satu kebutuhan yang tidak dapat ditawar kembali di era informasi yang serba terbuka seperti sekarang ini (Abdelrahman \& Bsharah, 20I4; Jackson \& McClelland, I979). Hal ini dikarenakan dengan semakin banyaknya informasi yang didapatkan, maka semakin membutuhkan banyak waktu untuk membaca semua sumber informasi yang didapatkan tersebut (Kamalasari, 20I2; Magno, 2010), salah satunya dapat dilakukan melalui keterampilan membaca cepat (Sinin, 2015; Yunhadi, 2019). Dengan demikian, pembiasaan yang dikondisikan pada siswa kelas VII SMP untuk melakukan membaca cepat, menjadikan mereka akan lebih siap dan cepat dalam memahami informasi dari beragama sumber yang didapatkan (Maryamah \& Effendy, 2019; Sinin, 2015).

Penelitian keterampilan membaca cepat ini memberikan informasi mengenai subjek penelitian yang digunakan oleh para peneliti. Berdasarkan Gambar 3, menunjukkan bahwa siswa kelas VII SMP mendominasi sebagai subjek penelitian yang paling sering digunakan. Kondisi ini semakin menguatkan pendapat bahwa keterampilan membaca cepat harus dibiasakan dan diajarkan mulai dari siswa di Sekolah Menengah Pertama (SMP) (Nurhayati, 2015; Pamuji, 2017). Berdasarkan hasil penelitian ini, subjek penelitian masih didominasi oleh siswa kelas VII SMP, sehingga penelitian keterampilan membaca cepat yang akan dilakukan selanjutnya dapat menggunakan siswa kelas VIII dan IX di tingkat Sekolah Menengah Pertama (SMP) atau siswa di tingkat atasnya. 


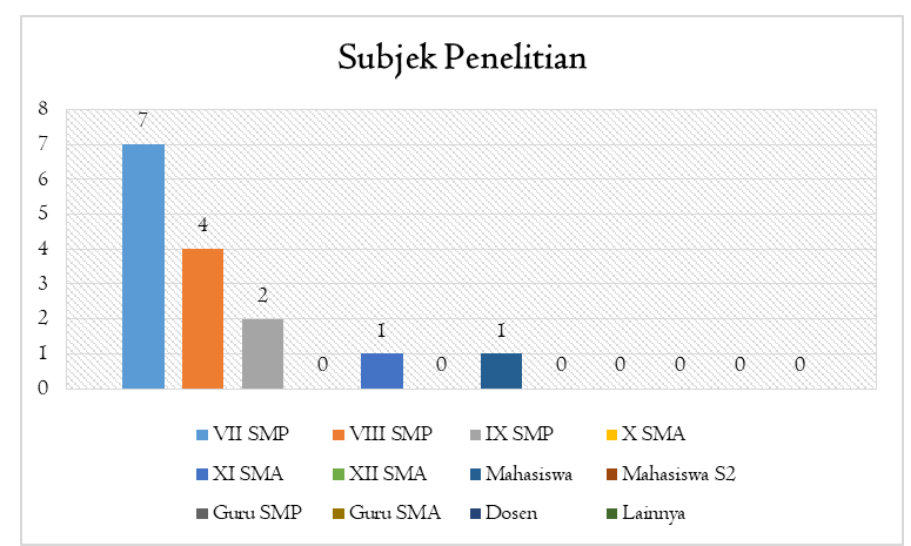

Gambar 3 Subjek Penelitian Keterampilan Membaca Cepat

\section{Instrumen Pengumpulan Data}

Berdasarkan grafik yang tersaji pada Gambar 4, menunjukkan bahwa instrumen pengumpulan data yang paling banyak digunakan oleh peneliti untuk mengetahui keterampilan membaca cepat adalah tes. Hal ini semakin menguatkan pendapat bahwa setiap penelitian yang dilakukan pasti memerlukan sebuah instrumen yang akan digunakan untuk mengumpulkan data (Mulyadi, 20II; Musianto, 2004). Keberadaan instrumen pengumpulan data akan membantu dan memudahkan peneliti dalam mengumpulkan data, utamanya mengenai keterampilan membaca cepat. Instrumen pengumpulan data dalam bentuk tes, merupakan instrumen yang paling banyak digunakan untuk mengukur keterampilan membaca cepat seperti yang dilakukan oleh (Ahyar \& Syahriandi, 20I5; Artanto, 2009; Pratama \& Yuniawan, 2015; Suniati et al., 2013). Instrumen dalam bentuk tes yang digunakan untuk menelaah keterampilan membaca cepat berfungsi untuk mengukur kecepatan membaca dan memahami teks bacaan (Acklin \& Papesh, 2017; Rayner, Schotter, Masson, Potter, \& Treiman, 2016) yang dikuasai oleh subjek penelitian. Selain itu, instrumen dalam bentuk tes juga dianggap sebagai salah satu alat pengumpulan data yang paling objektif (Ahn, Legge, \& Luebker, I995; Calef, Pieper, \& Coffey, I999) dibandingkan dengan instrumen pengumpulan data lainnya seperti lembar observasi, lembar kuesioner maupun lembar wawancara (Dingler, Shirazi, Kunze, \& Schmidt, 2015; Yen, 2012).

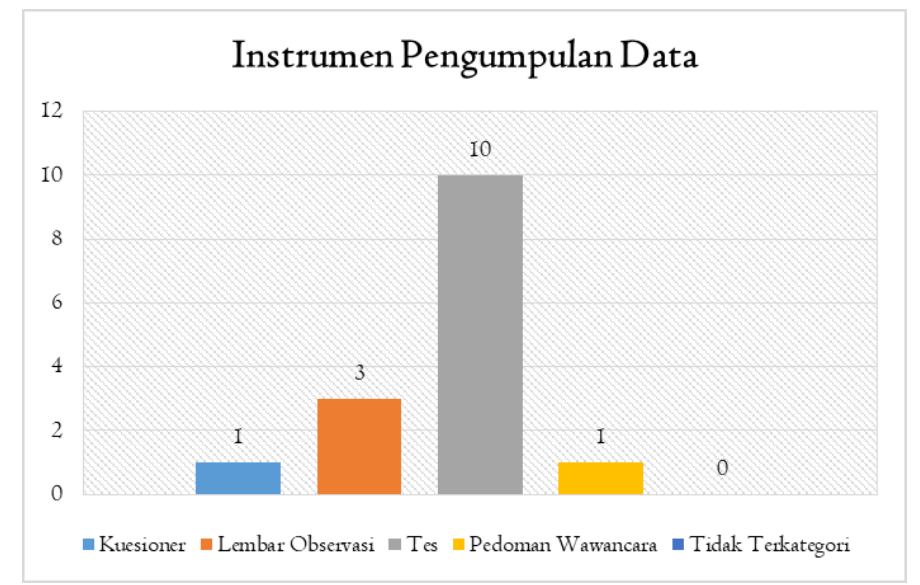

Gambar 4 Instrumen Pengumpulan Data Keterampilan Membaca Cepat

\section{Metode Analisis Data}

Keakuratan pemilihan metode untuk analisis data akan menentukan tingkat validitas sebuah penelitian. Berdasarkan Gambar 5 menunjukkan bahwa uji-t merupakan metode analisis data yang sering digunakan oleh para peneliti. Temuan ini telah mengklarifikasi bahwa para peneliti sering menggunakan uji-t untuk membandingkan prestasi dua kelompok atau kelas (Acklin \& Papesh, 2017; Rayner et al., 
2016). Berdasarkan data yang telah didapatkan, terdapat dua hal umum berkaitan dengan profil yang ditunjukkan oleh para peneliti dalam menggunakan uji-t sebagai uji hipotesis. Pertama, peneliti hanya mengambil data post-test dari masing-masing kelas, lalu memberikan kesaksian melalui uji-t. Kedua, para peneliti merujuk data pre-test dan post-test sebelum menghitung N-gain dari kedua data. Setelah itu, Ngain dari kedua kelas diperiksa dengan menggunakan uji-t. Tren semacam ini akan menurunkan tingkat validitas penelitian. Penggunaan metode analisis data yang tidak akurat ini sejalan dengan temuan yang ditunjukkan dalam penelitian (Fauzi \& Pradipta, 2018).

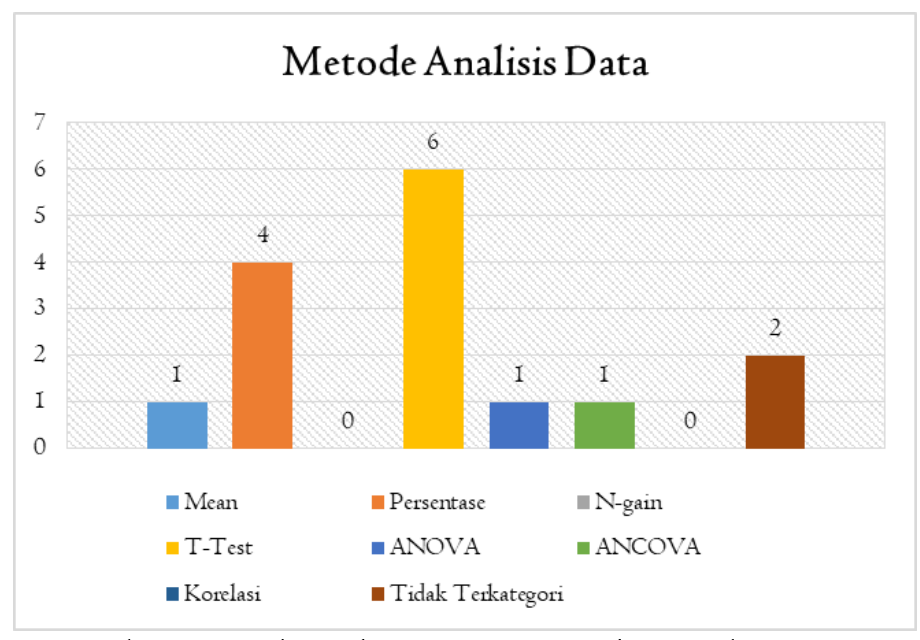

Gambar 5 Metode Analisis Data Keterampilan Membaca Cepat

Penggunaan metode analisis data ANCOVA sangat dianjurkan terutama ketika para peneliti berusaha untuk memilih desain quasi-eksperimental. Hal ini didasarkan pada realitas bahwa para peneliti tidak dapat memilih siswa satu per satu sebagai subjek penelitian (hanya siswa di kelas yang ditentukan yang dimungkinkan terpilih). Dengan menggunakan metode analisis data ANCOVA dalam kondisi seperti itu, para peneliti dapat mengendalikan eksternal variabel yang mungkin mempengaruhi hubungan antara variabel independen dan variabel dependen (Ulfa, 202I). Selain itu, dengan menggunakan metode analisis data ANCOVA dapat mengidentifikasi perbedaan yang terjadi antara kelompok berdasarkan karakteristik subjek penelitian yang ditunjukkan dalam data pre-test (Istiqomah \& Indarini, 202I; Kusumawati \& Mawardi, 2016). Berdasarkan uraian yang telah disampaikan, dapat ditarik kesimpulan bahwa penggunaan metode analisis data ANCOVA sangat direkomendasikan untuk penelitian quasieksperimental dengan pre-test dan post-test data (Istiqomah \& Indarini, 202I; Kusumawati \& Mawardi, 2016).

\section{Tahun Publikasi}

Jumlah penelitian mengenai keterampilan membaca cepat yang telah didapatkan terjadi dalam kurun waktu tertentu. Melihat grafik yang ditampilkan pada Gambar 6, menunjukkan bahwa artikel keterampilan membaca cepat yang telah diriview ditemukan mulai dari tahun 20I4. Grafik pada Gambar 6, juga menunjukkan bahwa penelitian mengenai keterampilan membaca cepat tidak banyak mengalami pergeseran signifikan yang terjadi dari tahun ke tahun. Terbukti dengan data yang ditampilkan pada Gambar 6, bahwa tahun 2104-20I7 terjadi grafik yang bersifat statis, sedangkan untuk tahun 2018 menjadi tahun yang paling banyak dilakukan penelitian tentang keterampilan membaca cepat. Namun pada tahun 2019 dan 2020 mengalami penurunan yang cukup drastis dengan jumlah penelitian sebanyak I saja.

Berdasarkan grafik pada Gambar 6, menunjukkan bahwa semakin banyak dan tinggi penelitian yang dilakukan tentang keterampilan membaca cepat akan berdampak pada penyiapan SDM di abad 2I (Rau et al., 2018). Hal ini didasarkan pada asumsi bahwa di abad 2I dibutuhkan kecepatan dan 
pemahaman yang komprehensif dalam memahami informasi yang sangat banyak dari berbagai macam sumber yang didapatkan (Acklin \& Papesh, 2017; Calef et al., 1999). Penelitian mengenai keterampilan membaca cepat yang telah dilakukan, dapat menjadi bahan evaluasi untuk lebih meningkatkan lagi kegiatan atau penelitian membaca cepat di masa yang akan datang. Selain itu, penelitian mengenai keterampilan membaca cepat dapat dilakukan lebih intens di dalam lingkup pendidikan, karena lingkup pendidikan menjadi garda terdepan dalam menyiapkan sumber daya manusia yang siap menghadapi tantangan abad 2I (Maryamah \& Effendy, 2019; Nurhayati, 2015).

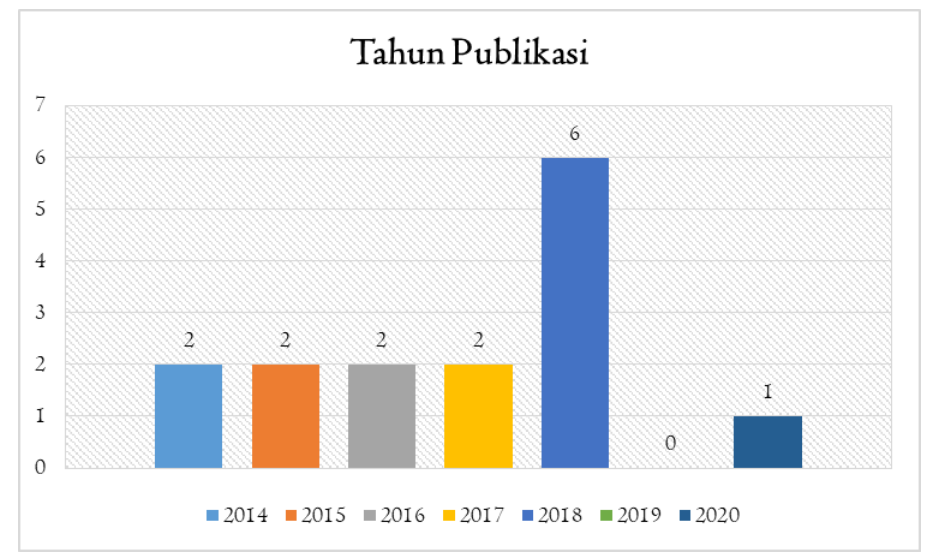

Gambar 6 Instrumen Pengumpulan Data Keterampilan Membaca Cepat

\section{SIMPULAN}

Berdasarkan hasil penelitian, menunjukkan bahwa profil penelitian keterampilan membaca cepat dapat dilihat berdasarkan (I) jenis penelitian, (2) jenis penelitian kuantitatif yang digunakan, (3) subjek penelitian, (4) instrumen pengumpulan data, (5) metode analisis data, dan (6) tahun publikasi. Adapun hasil penelitian sesuai dengan tujuan diuraikan sebagai berikut. (I) Profil penelitian keterampilan membaca cepat berdasarkan jenis penelitian yang digunakan menunjukkan bahwa jenis penelitian atau desain penelitian kuantitatif yang sering digunakan oleh peneliti. (2) Jenis penelitian kuantitatif yang dilakukan menunjukkan bahwa desain kuasi eksperimen menjadi desain yang paling dominan dilakukan oleh peneliti. (3) Subjek penelitian yang dominan digunakan dalam artikel penelitian keterampilan membaca cepat adalah siswa kelas VII SMP, kondisi ini didasarkan pada kenyataan bahwa keterampilan membaca cepat sangat tepat diajarakkan pada siswa Sekolah Menengah Pertama (SMP) khususnya kelas awal. (4) Instrumen pengumpulan data yang paling sering digunakan oleh peneliti adalah instrumen tes. Instrumen dalam bentuk tes berfungsi untuk mengukur kecepatan membaca dan memahami teks bacaan yang dikuasai oleh subjek penelitian. (5) Metode analisis data yang paling sering digunakan dalam penelitian keterampilan membaca cepat adalah uji-t. Temuan ini telah mengklarifikasi bahwa para peneliti sering menggunakan uji-t untuk membandingkan prestasi dua kelompok atau kelas. (6) Penelitian keterampilan membaca cepat telah dilakukan mulai dari tahun 2014-2020, dimana tahun 2018 merupakan tahun yang paling banyak dilakukan penelitian tentang keterampilan membaca cepat dengan jumlah 6 penelitian. Penelitian semacam ini akan menghasilkan informasi yang sangat berharga tentang profil keterampilan membaca cepat, serta sebagai dasar untuk menggiatkan keterampilan membaca cepat dalam dunia pendidikan sebagai salah satu bekal bagi siswa di abad 2I.

\section{UCAPAN TERIMA KASIH}

Penulis mengucapkan terima kasih kepada DPPM Universitas Muhammadiyah Malang yang telah memberikan dukungan dalam penelitian ini, serta semua pihak yang telah berkontribusi dalam penelitian ini, sehingga penelitian ini dapat terlaksana dan diselesaikan dengan baik. 


\section{DAFTAR PUSTAKA}

Abdelrahman, M. S. H. B., \& Bsharah, M. S. (20I4). The effect of speed reading strategies on developing reading comprehension among the 2nd secondary students in English Language. English Language Teaching, 7(6), I68-I74. Retrieved from https:// eric.ed.gov/?id=EJI075772

Abiyanti, E. (2017). Pengaruh keefektifan membaca cepat terhadap kemampuan menemukan ide pokok paragraf. DIKSATRASIA, I(2), 203-2II. Retrieved from https://jurnal.unigal.ac.id/index.php/diksatrasia/article/view/600/0

Acklin, D., \& Papesh, M. H. (2017). Modern speed-reading apps do not foster reading comprehension. American Journal of Psychology, I30(2), I83-I99. https://doi.org/I0.5406/amerjpsyc.I30.2.0183

Ahn, S. J., Legge, G. E., \& Luebker, A. (I995). Printed cards for measuring low-vision reading speed. Vision Research, 35(13), 1939-1944. https:// doi.org/I0.1016/0042-6989(94)00294-V

Ahyar, J., \& Syahriandi, S. (20I5). Membaca-cepat-pemahaman mahasiswa Universitas Malikussaleh. Jurnal Visioner \& Strategis, 4(2), I-9. Retrieved from https:/ / repository.unimal.ac.id/2302/I/Jurnal.pdf

Amalia, F. N. (2019). Peningkatan keterampilan membaca cepat dengan teknik skimming. Jurnal Ilmiah Bina Edukasi, I2(OI), 3I-4I. https:// doi.org/ttps:// doi.org/I0.33557/jedukasi.vI2i0I.479

Arifin, Z. (2020). Metodologi penelitian pendidikan. Jurnal Al-Hikmah, I(I), I-5. Retrieved from http://alhikmah.stit-alhikmahwk.ac.id/index.php/awk/article/view/I6

Artanto, D. (2009). Peningkatan Kemampuan membaca cepat menggunakan metode gerak mata pada siswa kelas X SMK Muhammadiyah 2 Surakarta. Tesis tidak Diterbitkan. Surakarta: Universitas Muhammadiyah Surakarta.

Bozkaya, M., Aydin, I. E., \& Kumtepe, E. G. (20I2). Research trends and issues in educational technology: A content analysis of TOJET (2008-20II). Turkish Online Journal of Educational Technology-TOJET, II(2), 264-277. Retrieved from https:// eric.ed.gov/?id=EJ989035

Brozo, W. G., \& Johns, J. L. (1986). A content and critical analysis of 40 speed reading books. Journal of Reading, 30(3), 242-247. Retrieved from https://www.jstor.org/stable/40032813

Calef, T., Pieper, M., \& Coffey, B. (I999). Comparisons of eye movements before and after a speedreading course. Journal of the American Optometric Association, 7O(3), I7I-I8I. Retrieved from https:// core.ac.uk/download/pdf/2I2798966.pdf

Chang, Y.-H., Chang, C.-Y., \& Tseng, Y.-H. (20I0). Trends of science education research: An automatic content analysis. Journal of Science Education and Technology, I9 4), 3I5-33I. Retrieved from https://link.springer.com/article/I0.I007\%2FsI0956-009-9202-2

Dingler, T., Shirazi, A. S., Kunze, K., \& Schmidt, A. (20I5). Assessment of stimuli for supporting speed reading on electronic devices. In Proceedings of the 6th Augmented Human International Conference (pp. II7-I24).

Fauzi, A., \& Pradipta, I. W. (2018). Research methods and data analysis techniques in education articles published by Indonesian biology educational journals. JPBI (Jurnal Pendidikan Biologi Indonesia), 4(2), I23-I34. https://doi.org/https://doi.org/I0.222I9/jpbi.v4i2.5889

Goktas, Y., Hasancebi, F., Varisoglu, B., Akcay, A., Bayrak, N., Baran, M., \& Sozbilir, M. (2012). Trends in educational research in Turkey: A content analysis. Educational Sciences: Theory and Practice, I2(I), 455-460. Retrieved from https:// eric.ed.gov/?id=EJ978453

Hosen, M. (20I6). Peningkatan kemampuan membaca cepat dengan metode SQ3R pada siswa kelas V SDN Gili Anyar Kamal Bangkalan. Widyagogik: Jurnal Pendidikan dan Pembelajaran Sekolah Dasar, 4(I), I7-32. https:/ / doi.org/https:/ / doi.org/I0.2I I07/widyagogik.v4iI.22I3

Inawati, I., \& Sanjaya, M. D. (2018). Kemampuan membaca cepat dan pemahaman siswa kelas V SD Negeri OKU. Jurnal Bindo Sastra, 2(I), I73-I82. https://doi.org/ttps://doi.org/I0.32502/jbs.v2iI.927

Istiqomah, J. Y. N., \& Indarini, E. (202I). Meta analisis efektivitas model problem based learning dan 
problem posing terhadap kemampuan berpikir kritis siswa sekolah dasar pada pembelajaran matematika. Jurnal Cendekia: Jurnal Pendidikan Matematika, 5(I), 670-68I. https://doi.org/https://doi.org/I0.3I004/cendekia.v5iI.553

Jackson, M. D., \& McClelland, J. L. (1979). Processing determinants of reading speed. Journal of Experimental Psychology: General, IO8(2), I5I-I62. https://doi.org/I0.I037/00963445.108.2.15I

Januarti, N. K., Dibia, I. K., \& Widiana, I. W. (2016). Analisis kesulitan belajar dalam pembelajaran membaca cepat siswa kelas V SD gugus VI Kecamatan Abang. MIMBAR PGSD Undiksha, 4(I), I-IO. https:// doi.org/http://dx.doi.org/I0.23887/jipgsd.v4iI.7442

Kamalasari, V. (20I2). Latihan membaca cepat sebagai upaya meningkatkan kemampuan membaca cepat dan pemahaman bacaan. Basastra, I(I), I-I6. https://doi.org/I0.24II4/bss.vIiI.I89

Kapborg, I., \& Berterö, C. (2003). The phenomenon of caring from the novice student nurse's perspective: a qualitative content analysis. International Nursing Review, 50(3), I83-192. https://doi.org/https://doi.org/I0.I046/j.I466-7657.2003.00196.x

Kusumawati, H., \& Mawardi, M. (20I6). Perbedaan penerapan model pembelajaran kooperatif tipe NHT dan STAD ditinjau dari hasil belajar siswa. Scholaria: Jurnal Pendidikan dan Kebudayaan, 6(3), 25I-263. https://doi.org/https://doi.org/I0.24246/j.scholaria.20I 6.v6.i3.p25I-263

Magno, C. (2010). The effect of scaffolding on children's reading speed, reading anxiety, and reading proficiency. TESOL Journal, 3(2), 92-I03. Retrieved from https://www.tesol-internationaljournal.com/wp-content/uploads/2013/II/A6_V3_TESOL.pdf

Maryamah, M., \& Effendy, M. H. (2019). Penerapan media audio visual dalam pembelajaran keterampilan membaca cepat pada siswa kelas XI di MA Al-Falah Tlanakan Pamekasan. GHANCARAN: Jurnal Pendidikan Bahasa dan Sastra Indonesia, I(I), I-9. https:/ / doi.org/sa Indonesia https:// doi.org/I0.I9I05/ghancaran.vIiI.2990

Mohajan, H. K. (2018). Qualitative research methodology in social sciences and related subjects. Journal of Economic Development, Environment and People, 7(I), 23-48. Retrieved from https://www.ceeol.com/search/article-detail?id=640546

Muhibbin, A., \& Sumarjoko, B. (2016). Model pembelajaran Pendidikan Kewarganegaraan berbasis isuisu kontroversial di media massa untuk meningkatkan sikap demokrasi mahasiswa dan implikasinya bagi masyarakat madani. Jurnal Pendidikan Ilmu Sosial, 26(I), I-I0. https://doi.org/I0.2317/jpis.v26iI.2035

Mulyadi, M. (20II). Penelitian kuantitatif dan kualitatif serta pemikiran dasar menggabungkannya. Jurnal Studi Komunikasi dan Media, I5(I), I28-I37. http://dx.doi.org/I0.3I445/jskm.20II.I50I06

Mulyani, M. (20II). Model pembelajaran menulis berbasis kearifan lokal yang berorientasi pendidikan karakter studi kuasi eksperimen pada siswa SMPN 2 kelas VII, Windusari, Magelang. Pena: Jurnal Pendidikan Bahasa dan Sastra, I(I), 93-I09. Retrieved from https://onlinejournal.unja.ac.id/pena/article/view/I427

Musianto, L. S. (2004). Perbedaan pendekatan kuantitatif dengan pendekatan kualitatif dalam metode penelitian. Jumal Manajemen dan Kewirausahaan, 4(2), I23-I35. https://doi.org/I0.9744/jmk.4.2.pp.\%20123-I36

Nurani, H. I., Suhita, R., \& Suryanto, E. (2017). Peningkatan kemampuan membaca cepat dengan metode SQ3R pada siswa SD. Paedagogia, 20(I), 33-49.

Nurhayati, H. (2015). Peningkatan kemampuan membaca cepat melalui pendekatan latihan persepsi. Dinamika Pendidikan, 5(2), I3-19. Retrieved from http://www.irpp.com/index.php/dinamika/article/view/I87

Pamuji, D. S. (2017). Kemampuan membaca cepat dengan metode skimming siswa kelas XI IPS SMA Negeri 3 Merlung Tahun Ajaran 2016/2017. Pena: Jurnal Pendidikan Bahasa dan Sastra, 6(2), 70-83. https://doi.org/I0.22437/pena.v7iI.4369 
Permana, Y., Sulistyowarni, D., \& Irmayanti, M. (2016). Pengaruh metode SQ3R terhadap kemampuan membaca cepat siswa kelas V Sekolah Dasar. Mimbar Sekolah Dasar, 3(2), 23I-240. https://doi.org/https://doi.org/10.23819/mimbar-sd.v3i2.4385

Pratama, H. A. A., \& Yuniawan, T. (2015). Peningkatan keterampilan membaca cepat untuk menemukan ide pokok dengan menggunakan strategi membaca fleksibel dan metode think, pair, and share. Lingua, $\quad I I(2), \quad I-I 7 . \quad$ Retrieved from https://journal.unnes.ac.id/nju/index.php/lingua/article/view/8766

Rau, P.-L. P., Zheng, J., Guo, Z., \& Li, J. (2018). Speed reading on virtual reality and augmented reality. Computers \& Education, I25, 240-245. https://doi.org/I0.I0I6/j.compedu.2018.06.016

Rayner, K., Schotter, E. R., Masson, M. E. J., Potter, M. C., \& Treiman, R. (2016). So much to read, so little time: How do we read, and can speed reading help? Psychological Science in the Public Interest, I7 I), 4-34. https:/ / doi.org/IO.II77/I529I006I5623267

Saputri, A. C., Sajidan, Rinanto, Y., Afandi, \& Prasetyanti, N. M. (2019). Improving students' critical thinking skills in cell-metabolism learning using Stimulating Higher Order Thinking Skills model. International Journal of Instruction, I3(3), 23-36. https://doi.org/I0.29333/iji.2019.I2I22a

Sari, K. R., Zulela, M. S., \& Boeriswati, E. (2017). Keterampilan membaca cepat melalui metode resitasi. Jurnal Pendidikan Dasar, 8(2), 79-88. Retrieved from http://journal.unj.ac.id/unj/index.php/jpd/article/view/5353

Shakouri, N., \& Nazari, O. (20I4). Qualitative research: Incredulity toward metanarrativeness. Journal of Education and Human Development, 3(2), 67I-680. Retrieved from http://jehdnet.com/journals/jehd/Vol_3_No_2_June_20I4/40.pdf

Sharma, S. (2013). Qualitative approaches in mathematics education research: Challenges and possible solutions. Education Journal, 2(2), 50-57.

Sinin, Y. (2015). Peningkatan kemampuan membaca cepat melalui penerapan metode gerak mata siswa kelas XII IPA A SMA Karuna Dipa Palu. BAHASANTODEA, 3(I), 99-I08. Retrieved from http://jurnal.untad.ac.id/jurnal/index.php/Bahasantodea/article/view/5190/396I

Suciyati, A., \& Adian, T. (2018). Developing the fun and educative module in plant morphology and anatomy learning for tenth graders. JPBI (Jurnal Pendidikan Biologi Indonesia), 4(I), 53-60. https://doi.org/https://doi.org/I0.222I9/jpbi.v4iI.5334

Suniati, N. M. S., Sadia, I. W., \& Suhandana, G. A. (2013). Pengaruh implementasi pembelajaran kontekstual berbantuan multimedia interaktif tehadap penurunan miskonsepsi (studi kuasi eksperimen dalam pembelajaran cahaya dan alat optik di SMP Negeri 2 Amlapura). Jurnal Administrasi Pendidikan Indonesia, 4(I), I-I3. https://doi.org/I0.23887/japi.v4iI.IOI9

Susetyarini, E., \& Fauzi, A. (2020). Trend of critical thinking skill researches in biology education journals across Indonesia: From research design to data analysis. International Journal of Instruction, I3(I), 535-550. https://doi.org/I0.29333/iji.2020.I3I35a

Trihantoro, A., Hidayat, D. R., \& Chanum, I. (2016). Pengaruh teknik biblioterapi untuk mengubah konsep diri siswa (Studi kuasi eksperimen pada siswa kelas VIII SMP Negeri 2 Tangerang). Insight: Jurnal Bimbingan Konseling, 5(I), 8-I4. https://doi.org/https://doi.org/I0.2I009/INSIGHT.05I.02

Ulfa, R. (202I). Variabel penelitian dalam penelitian pendidikan. AL-Fathonah, I(I), 342-35I. retrieved from file:///C:/Users/lenovo/Downloads/44-Article\%20Text-99-I-I0202104I5.pdf

Yen, T. T. N. (2012). The effects of a speed reading course and speed transfer to other types of texts. RELC Journal, 43(I), 23-37. https://doi.org/IO.I I77/00336882I2439996 
Yunhadi, W. (2019). Meningkatkan kemampuan membaca cepat melalui teknik skimming dan scanning. Intelegensia: Jurnal Pendidikan dan Pembelajaran, 4(I), I2-24.

Zuhara, E. (20I5). Efektivitas teknik sosiodrama untuk meningkatkan komunikasi interpersonal siswa (penelitian kuasi eksperimen kelas X di SMA Kartika Siliwangi 2 Bandung tahun ajaran 2013/2014). Jurnal Edukasi: Jurnal Bimbingan Konseling, I(I), 80-89. https://doi.org/http://dx.doi.org/I0.22373/je.vIiI.3I9 